\title{
PERAN BUDAYA ORGANISASI TERHADAP KOMITMEN ORGANISASI DITINJAU DARI PERSEPSI DOSEN UNIVERSITAS TERBUKA
}

\author{
Cherly Kemala Ulfa ${ }^{1}$,Ari Juliana ${ }^{2}$ dan Aulia Keiko Hubbansyah ${ }^{3}$
}

\begin{abstract}
1,2Universitas Terbuka, Indonesia 3Universitas Diponegoro, Indonesia 1'cherly@ecampus.ut.ac.id 2ari@ecampus.ut.ac.id ${ }^{3}$ keikohubbansyah91@gmail.com
\end{abstract}

Submitted: 1 Juli 2020

Revised: 2 Agustus 2020 Accepted: 3 November 2020

\begin{abstract}
In the New Normal Era, Universitas Terbuka (UT) emerged as the leading Open Distance Learning Organization. In order to survive and excel, Universitas Terbuka requires a strong organizational commitment from lecturers who are important elements in the learning system at UT. This article aims to examine the influence of organizational culture on organizational commitment for Universitas Terbuka's lecturers. This was a correlational quantitative research conducted at the UT Headquarters and UT regional offices (UPBJJ UT). The sampling technique used was purposive sampling. Analysis of Simple linier Regression was used to test the hypothesis. The results showed that there was a positive and significant influence of organizational culture on the organizational commitment of UT lecturers. It means the more conducive the organizational culture adapted by the organization is, the higher the level of organizational commitment of UT lecturers have. The implication of this research could be a guide for the management to develop an organizational maintenance program which pays attention to the organizational culture.
\end{abstract}

Keywords: Organizational Culture, Commitment Organizational, Universitas Terbuka

\section{PENDAHULUAN}

Perubahan di segala aspek kehidupan disebabkan pandemi Covid-19 berhasil mendisrupsi wajah pendidikan di Indonesia. Pembelajaran online menjadi strategi bertahan di tengah krisis, sehingga hal ini menuntut banyak institusi pendidikan harus beradaptasi dan mengubah modus pembelajaran menjadi daring ( dalam jaringan). Berbeda dengan Universitas Terbuka, sebagai Perguruan Tinggi Jarak Jauh yang terbesar dan telah beroperasi selama 36 tahun, Universitas Terbuka muncul sebagai primadona di tengah krisis, semakin diperhitungkan dan dipercaya sebagai salah satu pilihan Universitas Negeri yang paling berpengalaman melaksanakan pembelajaran online atau daring, atau dapat dikatakan
Universitas Terbuka adalah yang terdepan dalam inovasi dan pembelajaran tinggi dan terbuka saat ini. Bahkan kini setelah 36 tahun UT berdiri, direncanakan UT akan dikembangkan menjadi sebuah Cyber University.

Kesiapan untuk beroperasi sebagai Universitas siber tentu saja memerlukan banyak persiapan dan kekuatan pendukung dari berbagai unsur. Elemen yang sangat penting dan menjadi fokus dalam penyelenggaraan sebuah pendidikan tinggi adalah dosen. Dosen merupakan warga organisasi yang menjadi instrumen penting dalam proses belajar dan mengajar yang berlangsung dalam pendidikan tinggi. Dosen adalah pendidik profesional dan ilmuwan dengan tugas utamanya mentransformasikan, mengembangkan, dan menyebarluaskan ilmu pengetahuan (Undang- 
Undang No 14). Dosen UT, selain bertugas melaksanakan Tridharma Pendidikan, juga bertanggungjawab untuk menangani administrasi Pendidikan Jarak Jauh atau halhal yang berkaitan dengan tugas administratif pendidikan jarak jauh. Dosen UT pada dasarnya memiliki tugas dan tanggungjawab yang sama dengan dosen konvensional, akan tetapi pada praktiknya mereka lebih banyak menghabiskan pelaksanaan tugas administrative, yang pada universitas konvensional di kendalikan dan dilaksanakan oleh tenaga pendidik.

Untuk mencapai keunggulan diperlukan dosen yang memiliki komitmen organisasi yang tinggi, dimana hal ini terwujud dalam kesediaannya untuk bekerja lebih giat. Tidak hanya akan membatasi diri pada pelaksanaan tugas-tugas pokok ataupun tugas yang diperintahkan saja, akan tetapi juga melibatkan dirinya secara penuh ke dalam dinamika organisasi. Pekerja dengan komitmen organisasi yang tinggi cenderung punya rasa keterikatan yang kuat dengan organisasi tempatnya bertugas. Ini yang membuat pekerja yang memiliki komitmen organisasi yang tinggi menjadi loyal terhadap organisasi tempatnya bekerja. Kondisi yang bertolak belakang didapati pada pekerja yang tidak berkomitmen. Pekerja yang tidak berkomitmen memiliki tingkat penerimaan yang rendah terhadap nilai-nilai organisasi. Ini membuat rasa keterikatan pekerja terhadap organisasi menjadi lemah. Pekerja dengan komitmen organisasi yang rendah cenderung tidak seutuhnya melibatkan diri dan menjadi bagian dari organisasi. Jangankan untuk bekerja lebih dari apa yang menjadi tugas pokoknya, untuk sekedar memenuhi tugas pokoknya saja, pekerja dengan tingkat komitmen organisasi yang rendah sudah mengalami kesulitan. Tentu hal ini berakibat pada kinerjanya menjadi rendah. Dengan demikian kehadiran pekerja dengan komitmen organisasi yang rendah akan berdampak regresif atau korosif bagi kemajuan organisasi. Pentingnya kontribusi komitmen organisasi yang dimiliki pekerja inilah yang menjadi alasan mengapa informasi mengenai komitmen organisasi dosen perlu diteliti lebih jauh,

Berkaitan dengan hal di atas, secara empirik, ada beberapa faktor yang terbukti memiliki pengaruh dengan komitmen organisasi pegawai dalam hal ini profesi dosen. Yang berpengaruh cukup besar adalah budaya organisasi (Ghina, 2012). Menurut Robbins, et al, (2009), menyebutkan budaya organisasi adalah nilai-nilai yang disepakati bersama oleh para anggota organisasi yang membedakannya dengan organisasi lain. Dalam aspek operasional peran budaya organisasi sangat diperlukan untuk melancarkan kegiatan organisasi, dan membantu organisasi untuk dapat mencapai tujuannya. Peran fungsional dari budaya organisasi yang paling utama adalah menjadi kerangka acuan bagi setiap anggota organisasi dalam bertindak dan berperilaku sebagaimana yang diharapkan oleh organisasi. Peran budaya dalam konteks fungsional ini menjadi penting oleh karena organisasi sendiri merupakan kumpulan sekelompok orang yang saling bekerja sama sehingga memang memerlukan standar acuan yang disepakati bersama, apakah itu dalam bentuk nilai-nilai ataupun norma-norma. Menurut Ghina (2012), budaya organisasi yang baik, yakni yang mendukung kemajuan dan perkembangan tiap anggota organisasi, akan mampu menghasilkan suasana kerja yang kondusif. Budaya organisasi yang baik dapat mereduksi ketidakpastian, menciptakan keberlanjutan, membentuk komitmen dan identitas kolektif, serta dapat menerangkan visi organisasi di masa depan.

Terkait Dosen UT yang bekerja dalam struktur birokrasi, budaya organisasi yang melingkupinya diduga masih relatif bersifat birokratif.Dalamsituasiyang demikianini, budaya organisasi yang ada dapat menjadi tidak cukup suportif karena sifatnya yang cenderung topdown. Dalam pelaksanaan pekerjaannya, Dosen harus mengikuti perintah. Kompleksitas budaya organisasi semacam ini dapat berkontribusi terhadap komitmen organisasi pegawai menjadi lebih rendah. Oleh karena budaya organisasi yang dikembangkan bukannya mereduksi, tapi 
justru mendorong munculnya ketidakpastian. Penelitian ini bertujuan mendapatkan informasi berkaitan dengan kondisi komitmen organisasi dan budaya organisasi yang dimiliki oleh dosen di Universitas Terbuka.

\section{KAJIAN TEORITIS}

\section{Komitmen Organisasi}

Komitmen organisasi, secara definitif, dimaknai secara beragam. Komit-men organisasi dapat dimaknai sebagai tingkat identifikasi diri pegawai terhadap organisasi, dan keinginannya untuk meneruskan partisipasi aktif dalam organisasi (Newstrom, 2007). Komitmen organisasi juga bisa dimaknai dengan hasrat yang kuat dari pegawai untuk tetap menjadi anggota organisasi; keinginan untuk mem-berikan usaha tingkat tinggi atas nama organisasi; dan keinginan yang kuat untuk menerima nilainilai dan tujuan-tujuan organisasi (Luthans, 2008; Mowday, 2008). Dengan demikian, pada dasarnya, komitmen organisasi secara konseptual meliputi tiga hal, yakni pertama, keterlibatan diri pegawai ke dalam kegiatan orga-nisasi; kedua, penerimaan terhadap nilai-nilai dan tujuan organisasi dan kesiapan untuk berusaha dengan sungguh-sungguh atas nama organisasi; ketiga, keinginan untuk tetap mempertahankan keanggotaan dalam organisasi.

Komitmen organisasi dalam diri pegawai dapat diamati dari sejauhmana tingkat loyalitas, identifikasi diri dan keterlibatannya dalam organisasi (Robbins, et.al, 2011). Dalam hal ini, makin kuat derajat orientasi individu terhadap organi-sasi, maka akan semakin rendah pula keinginannya untuk meninggalkan organisa-si (Greenberg, et.al, 2012). Dengan demikian, ada hubungan yang terbalik antara derajat komitmen organisasi pegawai dengan intensi untuk keluar dari organisasi. Pegawai dengan komitmen yang tinggi akan merasa yakin dan menerima tujuan organisasional serta berkeinginan untuk terus tinggal bersama organisasi tersebut (Mathins, et al, 2006). Dari beberapa definisi di atas dapat disimpulkan bahwa komitmen organisasi dapat didefinisikan sebagai suatu perasaan positif yang ada dalam diri individu atas keterlibatannya dalam organisasi, dimana individu beru-saha untuk mengidentifikasikan dirinya pada iklim organisasi sehingga muncul keinginan untuk tidak akan meninggalkan organisasi.

Robbins (2011) melakukan pengelompokkan komitmen organisasi ke dalam tiga dimensi yaitu:

1. Komitmen Afektif (Affective Commitment), merupakan perasaan emosional untuk organisasi dan keyakinan di dalam nilainilainya. Seseorang yang memiliki komitmen efektif yang kuat akan terus bekerja dalam suatu organisasi karena mereka memang ingin melakukan hal tersebut.

2. Komitmen Berkelanjutan (Continuance Commitment), merupakan nilai ekonomi yang dirasakan dari bertahan dalam suatu organisasi dibandingkan dengan meninggalkan organisasi tersebut. Seorang karyawanmungkin bertahan dan berkomitmen dengan organisasi dan pemberikerja karena diberi imbalan yang cukup tinggi. Komitmen ini menyebabkan seorang karyawanbertahan pada suatu organisasi karena mereka membutuhkannya.

3. Komitmen Normatif (Normative Commitment), merupakan kewajiban seseorang untuk bertahan di dalam suatu organisasi untuk alasan-alasan moral dan etis. Komitmen ini menyebabkan seorang karyawan bertahan pada suatu pekerjaan karena mereka merasa wajib untuk melakukannya. Dengan kata lain, komitmen normative itu berkaitan dengan perasaan wajib untuk tetap bekerja dalam sebuah organisasi.

4. Komitmen efektif (Affektive Commitment), komitmen berkelanjutan (Continuance Commitment), dan komitmen normatif (Normative Commitment), dapat digunakan dalam menguji komitmen organisasi pada sebuah perusahaan. Seorang aparatur pemerintah yang berkerja dalam suatu organisasi harus memiliki komitmen dalam 
menjalankan tugasnya. Komitmen seorang aparatur pemerintah berhubungan dengan faktor-faktor seperti perasaan emosional untuk organisasi juga keyakinan di dalam nilai-nilainya, nilai ekonomi yang dirasakan oleh seorang aparatur pemerintah tersebut dalam bertahandi organisasinya dan juga adanya alasan-alasan moral atau etis.

Faktor lainnya yang menentukan tinggi rendahnya komitmen organisasi pekerja, yaitu:

1. Faktor demografis individual

\section{Usia}

Usia dan masa kerja, menurut LaMastro (2002), menunjukkan hubungan yang positif dengan komitmen. Kesempatan untuk mendapatkan pekerjaan lain menjadi semakin terbatas sejalan dengan meningkatnya usia dan masa kerja. Keterbatasan tersebut dapat dipersepsi yang lebih positif mengenai atasan sehingga meningkatkan komitmen. Sehingga, semakin bertambah usia dan pengalaman kerjanya, komitmen mereka terhadap organisasi akan cenderung meningkat.

\section{Jenis kelamin}

Sebagai contoh, wanita cenderung memiliki komitmen yang lebih tinggi dibandingkan pria. Wanita pada umumnya harus mengatasi lebih banyak rintangan dalam mencapai posisi mereka dalam organisasi sehingga keanggotaan bagi mereka menjadi lebih penting (Temaluru, 2001).

\section{Pendidikan}

Dalamhalini,individuyang berpendidikan rendah cenderung memiliki komitmen yang lebih tinggi daripada yang berpendidikan tinggi. Hal ini karena individu berpendidikan tinggi semakin banyak harapannya yang mungkin tidak dapat dipenuhi atau sesuai dengan organisasi tempat bekerja (Cherington, 1994). Sedangkan LaMastro (2002) mengemukakan bahwa tingkat pendidikan memiliki hubungan yang negatif dengan komitmen.

2. Karakteristik keadaan kerja

\section{Sifat kerja}

Pekerjaan yang memiliki lingkup kerja lebih luas dan menuntut sumbangan ide-ide cenderung membuka kesempatan kepada individu untuk memikul tanggung jawab yang lebih tinggi. Hal ini menyebabkan individu akan memiliki komitmen organisasi lebih tinggi daripada pekerjaan dengan ruang lingkup sempit dan rutinitias terbatas yang akan memicu munculnya kebosanan.

\section{Perilaku supervisor}

Supervisor sebagai atasan yang berhubungan langsung dengan karyawan dapat memunculkan komitmen organisasi. Hal ini karena sikap dan tindakan supervisor dapat memhubungani sikap dan perilaku karyawan. Dalam suatu studi disebutkan bahwa turn over dapat disebabkan oleh pengawasan yang kurang baik dari supervisor (Robbins, 2011).

\section{Faktor psikologi pribadi}

\section{Kebutuhan}

Seseorang dengan tingkatan kebutuhan berprestasi yang tinggi, minat hidup yang berorientasi kerja, dan rasa bersaing akan memiliki hubungan yang positif dengan komitmen organisasi.

\section{Sistem nilai pribadi}

Organisasi yang memiliki karyawan dengan tingkat komitmen yang tinggi akan mempunyai karyawan dengan rasa keterikatan dan pengabdian yang besar pada organisasi. Organisasi yang memiliki komitmen tinggi akan menguntungkan organisasi karena akan memudahkan organisasi dalam mencapai tujuannya. Menciptakan karyawan pada organisasi sangat penting, karena karyawanlah yang menentukan sebagian besar keberhasilan suatu organisasi.

\section{BUDAYA ORGANISASI}

Budaya adalah totalitas pola perilaku, seni, kepercayaan, kelembagaan dan semua produk lain dari hasil karya dan pemikiran manusia yang membedakan antara satu kelompok masyarakat dengan kelompok masya-rakat yang lain (Kottler, et.al, 1997). Adapun budaya dalam arti yang lebih 
luas meliputi juga di dalamnya simbol, bahasa, ideologi, ritual, mitos, aturan organisasi, capaiancapaian dan produk-produk hasil pemikiran manusia lainnya. Sedangkan, organisasi diartikan sebagai sekelompok orang yang saling bekerja dan bergabung untuk mencapai tujuan tertentu (McShane, et.al, 2008). Secara lebih rinci, organisasi dapat juga dijelaskan sebagai sistem sosial yang terstruktur, terdiri dari kelompok dan individu yang bekerja sama untuk memenuhi sasaran yang telah disepakati (Greenberg, et.al, 2010).

Adapun pemaknaan yang lebih menekankan aspek fungsional dari organisasi memahami organisasi sebagai alat yang dipakai oleh orang-orang untuk mengkoordinasikan tindakannya untuk memperoleh sesuatu yang diinginkan. Dari beberapa penjelasan mengenai organi-sasi di atas, terdapat beberapa kata kunci yang perlu diperhatikan, antara lain bahwa organisasi itu terdiri dari sekelompok orang, sistemnya terstruktur, dan digunakan untuk meraih tujuan-tujuan yang telah disepakati bersama oleh para anggota organisasi.

Dengan mengaitkan kedua kata "budaya" dan "organisasi" ke dalam istilah budaya organisasi, maka dapatlah dikatakan bahwa budaya organisasi merupakan nilai, norma, aturan, baik itu yang tertulis ataupun tidak tertulis, yang diadaptasi dalam suatu organisasi tertentu untuk mengatur dan mengarahkan pola perilaku, dan cara kerja anggota organisasi dalam rangka mencapai tujuan dan sasaran yang telah disepakai bersama (Zachary, et.al, 2005). Budaya organisasi bisa juga dilihat sebagai norma, nilainilai, asumsi, kepercayaan, filsafat, kebiasaan organisasi dan sebagainya yang dikembangkan dalam waktu yang lama baik itu oleh pendiri, pemimpin dan anggota organisasi yang disosialisasikan dan diajarkan kepada anggota baru serta diterapkan dalam aktivitas organisasi sehingga memhubungani pola pikir, sikap dan perilaku anggota organisasi dalam memproduksi produk, melayani para konsumen dan mencapai tujuan organisasi (Jones, et.al, 2012).
Budaya organisasi merupakan sistem makna bersama dengan nilai-nilai primer yang dianut bersama dan dihargai organisasi. Budaya organisasi secara umum memiliki fungsi sebagai berikut : a) Budaya menciptakan perbedaan yang jelas antara satu organisasi dengan organisasi yang lain; b) Budaya membawa suatu rasa identitas atau jati diri bagi anggota-anggota organisasi; c) Budaya mempermudah timbulnya komitmen pada sesuatu yang lebih luas dari pada kepentingan diri individu seseorang; d) Budaya merupakan perekat sosial yang membantu mempersatukan organisasi itu dengan memberi standar-standar yang tepat untuk dilakukan oleh karyawan; e) Budaya sebagai penuntun mekanisme pembuat makna dan kendali yang memandu dan membentuk sikap serta perilaku karyawan dan motivasi kerja yang baik. Budaya organisasi memiliki tujuh ciri-ciri yang spesifik dan besar hubungannya dengan organisasi, yaitu : a) Inovasi dan pengambilan resiko, sejauhmana karyawan didukung untuk menjadi inovatif dan mengambil resiko; b) Perhatian dengan detail, sejauhmana karyawan diharapkan menunjukkan kecermatan, analisis, dan perhatian dengan nilai detail; c) Orientasi hasil, sejauhmana manajemen memfous pada hasil bukan pada teknik dan proses yang digunakan untuk mencapai hasil tersebut; d) Orientasi orang, sejauhmana keputusan manajemen memperhitungkan efek pada orang-orang di dalam organisasi itu; e) Orientasi tim, sejauhmana kegiatan kerja diorganisasikan sekitar tim-tim, ukuran kepuasan individu; f) Keagresifan, erkaitan dengan agresifitas karyawan; g) Kemantapan, organisasi menekankan untuk mempertahankan budaya organisasi yang sudah baik (Robbins, 2012).

Budaya organisasi pada setiap organisasi dapat berbeda-beda, tergantung spesifikasinya. Itulah sebabnya para pakar juga mengidentrifikasi indikator atau dimensi budaya organisasi secara beragam.

Menurut Schein (1990) budaya organisasi merupakansalahsatucara dalammenghubungkan pola pikir individu dalam membuat keputusan 
dan akhirnya menghubungkan cara mereka dalam menerima, merasa dan bertindak. Budaya organisasi juga memiliki pola asumsi dan nilai-nilai bersama yang telah disesuaikan dengan organisasi melalui pengalaman belajar dan dianggap penting dipelajari oleh anggota organisasi yang baru (Schein, 2010). Selanjutnya Schein menyatakan bahwa budaya melibatkan asumsi, adaptasi, persepsi dan pembelajaran. Schein menggambarkan budaya organisasi terdiri dari tiga dimensi yaitu:

1. Artifak (artifact), adalah hal-hal yang dilihat dan didengar dan dirasa terhadap budaya yang dikenalnya, termasuk di dalamnya; teknologi, seni bahkan tingkah laku anggota kelompok yang merupakan lingkungan fisik dan sosial organisasi.

2. Nilai-nilai(values), adalah nilai-nilai yang di dukung merupakan alasan bahwa kita berkorban demi yang kita kerjakan. termasuk pengakuan atau penerimaan dari pihak anggota organisasi terhadap solusi yang diberikan pimpinan dalam mengatasi masalah yang dihadapi organisasi.

3. Asumsi dasar (basic assumption), yaitu asumsi yang dianggap benar oleh anggota organisasi berdasarkan pengalaman bahwa solusi yang diberikan oleh pimpinan telah berkali-kali ternyata benar. Pada tingkat ini, telah timbul kepercayaan dari anggota organisasi bahwa setiap solusi yang diberikan pimpinan selalu berhasil.

Berdasarkan beberapa pandangan di atas tampak bahwa budaya organisasi merupakan seperangkat nilai, norma, keyakinan dan asumsi yang dimiliki suatu organisasi, digunakan sebagai pedoman berperilaku dalam organisasi untuk menghadapi persoalan-persoalan eksternal dan internal, dengan dimensi meliputi, artefak dan kreasi, nilai-nilai, dan asumsi dasar.

\section{Hubungan Budaya dan Komitmen Organisasi}

Keefektifan suatu organisasi memiliki hubungan yang erat dengan budaya organisasi.
Budaya organisasi dimaknai sebagai norma, nilai-nilai, asumsi, kepercayaan, atau kebiasaan organisasi yang dikembangkan dalam waktu lama dan diajarkan ke setiap anggota, diterapkan dalam aktivitas organisasi sehingga memengaruhi pola pikir, sikap dan perilaku anggota organisasi. Dengan kata lain, budaya organisasi memiliki kontribusi dalam membentuk perilaku pegawai. Di dalamnya diatur dan dikembangkan berbagai fungsi manajerial, seperti cara organisasi merencanakan, meng-organisasi, memimpin dan mengawasi. Budaya organisasi yang dipersepsi secara positif oleh pegawai akan cenderung memiliki keterhubungan yang erat dengan pembentukan komitmen pegawai. Secara istilah, komitmen organisasi pegawai dipahami sebagai kekuatan atau derajat keterikatan pegawai dan keterlibatannya dengan organisasi. Pegawai berkomitmen senantiasa tetap bertahan dengan organisasi terlepas dari apapun kondisi yang dihadapi organisasi (Nongo, et al, 2012). Dalam hubungannya dengan komitmen pegawai, budaya organisasi bisa menjadi faktor yang merekatkan pegawai dengan organisasinya. Atau malah sebaliknya, ia bisa menjadi faktor yang membuat pegawai meninggalkan organisasi (Ghina, 2014). Dalam hal ini, budaya organisasi yang baik akan mampu mengha-silkan suasana yang kondusif dalam organisasi. Budaya organisasi yang baik mampu mereduksi ketidakpastian, menciptakan keberlanjutan, mem-bentuk komitmen dan identitas kolektif, dan menerangkan visi organisasi di masa depan (Shouaib, 2013). Dalam konteks budaya organisasi yang baik, yakni budaya yang memungkinkan pekerja dapat memahami tujuan organisasi dengan jelas, dapat meningkatkan rasa komitmen seseorang pada tempatnya bekerja (Nongo, et al, 2012). Dalam kaitannya dengan kedua variabel ini, Ghina (2012), Acar (2012), Shouaib (2013), Siburian (2013) menemukan bahwa terdapat hubungan yang positif dan signifikan antara budaya organisasi dengan komitmen organisasi pegawai. Oleh karena itu, berdasarkan uraian di atas, dapatlah diduga dalam konteks studi ini terdapat hubungan yang positif budaya organisasi dengan 
komitmen organisasi pada dosen. Inilah yang menjadi hipotesis dalam penelitian ini.

\section{METODE PENELITIAN}

Penelitian ini menggunakan pendekatan kuantitatif dengan jenis penelitian korelasional. Dalam konteks di atas, penelitian ini bertujuan menganalisis hubungan antara kondisi budaya organisasi, kecerdasan emosional dan kepuasan kerja terhadap komitmen organisasional pada dosen Universitas Terbuka. Populasi dalam penelitian ini adalah dosen UT baik yang bekerja pada Kantor Pusat Universitas Terbuka dan UPT UPBJJ di seluruh Indonesia. Jumlah dosen PNS seluruhnya berjumlah 624 orang, dengan perincian Dosen PNS 610 orang, Dosen BLU 4 orang dan dosen TKT 10 orang. Sampel penelitian yang direncanakan berjumlah 243 orang dosen, namun yang berhasil dikumpulkan sebanyak 130 orang. Analisis data dalam penelitian ini menggunakan Analisa Regresi sederhana.

\section{Hasil Penelitian}

\section{Hasil Uji coba Instrumen Penelitian}

Uji Coba Instrumen dalam Penelitian ini dilakukan dengan menganalisis hubungan skor tiap butir dengan skor total menggunakan rumus korelasi Pearson's Product Moment, dari perhitungan tersebut menghasil-kan butir-butir yang valid dan tidak valid (drop).

Untuk Instrumen Komitmen Organisasi diperoleh 29 butir valid, 7 tidak valid. Sementara hasil uji reliabilitas alat ukur $\mathrm{r}=0.949$

Hasil Uji Reliabilitas Instrumen Komitmen Organisasi

\begin{tabular}{cc}
\hline Cronbach's Alpha & Jumlah Item \\
\hline 0.949 & 29 \\
\hline
\end{tabular}

Untuk Instrumen Budaya Organisasi, seleuruh butir dalam instrument yakni 35 butir dinyatakan valid, dengan hasil uji reliabilitas alat ukur $\mathrm{r}=0,957$
Hasil Uji Reliabilitas Instrumen Budaya Organisasi

\begin{tabular}{l}
\hline Cronbach's Alpha \\
\hline 0.957 \\
\hline Hasil pengujian reliabilitas instrumen \\
penelitian budaya organisasi dan komitmen \\
organisasi menunjukkan nilai cronbach's alpha \\
sebesar o,949 dan o.957. Dengan demikian, \\
dapat disimpulkan bahwa instrumen penelitian \\
untuk mengukur komitmen organisasi sudah \\
reliabel atau konsisten.
\end{tabular}

\section{Hasil Uji Hipotesa}

Hipotesis dalam penelitian ini menyatakan bahwa variabel budaya organisasi memiliki pengaruh positif dan signifikan terhadap komitmen organisasi dosen. Dalam hal ini, maka hipotesis yang diuji adalah:

$$
\begin{aligned}
& \text { Ho }: \rho y, x=0 \\
& \text { H1 }: \rho y, x \neq 0
\end{aligned}
$$

Ho ditolak apabila thitung didapati lebih besar dari ttabel.

Tabel 4. 10 Hasil Uji Signifikansi Koefesien Pengaruh X Terhadap Y

\begin{tabular}{cccccc}
\hline \multirow{2}{*}{ Pengaruh } & Unstd. & & \multicolumn{3}{c}{$\mathrm{t}_{\text {tabel }}$} \\
\cline { 4 - 6 } & Koefesien & $\mathrm{t}_{\text {hitung }}$ & 10 & 5 & 1 \\
& & & persen & persen & persen \\
\hline Bud thd Kom & 0.288 & $3.474 * * *$ & 1.66 & 1.98 & 2.62 \\
\hline
\end{tabular}

Keterangan: ${ }^{* * *}=$ sangat signifikan pada taraf 1 persen

Dari tabel 4. 10 di atas dapat dilihat bahwa nilai koefesien budaya organisasi terhadap komitmen organisasi dosen adalah 0.288 dengan nilai thitung 3.474 yang lebih besar dari nilai ttabel untuk tingkat signifikansi 1 persen, yaitu 2.62. Karena nilai ttabel lebih besar dari nilai thitung, maka Ho pun ditolak, yang artinya budaya organisasi memiliki pengaruh yang positif 
dan signifikan terhadap komitmen organisasi dosen di Universitas Terbuka.

\section{PEMBAHASAN}

Komitmen organisasi dalam penelitian ini diukur dengan 29 butir pernyataan dengan total responden berjumlah 130 dosen. Dari hasil uji beda Anova diketahui bahwa tidak terdapat perbedaan nilai rata-rata komitmen organisasi dosen berdasarkan jenis kelamin, pendidikan, masa kerja, maupun jabatan fungsional. Sementara itu, secara deskriptif, terdapat perbedaan rata-rata untuk komitmen organisasi berdasarkan kategori usia. Di antara kelompok usia yang diamati, responden dengan rentang usia 41-50 tahun memiliki nilai rata-rata komitmen organisasi tertinggi, yakni 122. Budaya organisasi dalam penelitian ini diukur dengan 35 butir pernyataan dengan total responden berjumlah 130 dosen. Dari hasil uji beda Anova diketahui bahwa tidak terdapat perbedaan nilai rata-rata budaya organisasi dosen berdasarkan jenis kelamin, pendidikan, masa kerja, maupun jabatan fungsional. Secara deskriptif, terdapat perbedaan rata-rata untuk budaya organisasi berdasarkan kategori usia. Di antara kelompok usia yang diamati, responden dengan rentang usia 41-50 tahun memiliki nilai rata-rata budaya organisasi tertinggi, yakni 152.

Dari hasil uji hipotesis dapat disimpulkan bahwa, secara statistik, ada hubungan yang positif dan signifikan variabel budaya organisasi terhadap komitmen organisasi dosen. Ini artinya, semakin kondusif budaya organisasi yang diadaptasi oleh organisasi, maka akan semakin tinggi pula tingkat komitmen organisasi dosen.

Budaya organisasi dimaknai sebagai norma, nilai-nilai, asumsi, kepercayaan, atau kebiasaan organisasi yang dikembangkan dalam waktu lama dan diajarkan ke setiap anggota, diterapkan dalam aktivitas organisasi sehingga memengaruhi pola pikir, sikap dan perilaku anggota organisasi. Dengan kata lain, budaya organisasi memiliki kontribusi dalam membentuk perilaku dosen.

Berkaitan dengan hal di atas, budaya organisasi dapat memiliki hubungan dengan komitmen dosen secara positif hanya apabila budaya yang dikembangkan mampu menciptakan suasana yang kondusif di dalam organisasi. Dalam arti, budaya yang diadaptasi dalam organisasi tersebut akan mampu mereduksi ketidakpastian, menciptakan keberlanjutan, membentuk identitas kolektif dan menerangkan visi organisasi di masa depan (Shouaib, 2013). Budaya organisasi yang semacam ini dapat menghasilkan komitmen yang lebih kuat dalam diri dosen oleh karena memungkinkan dosen untuk lebih mampu memahami tujuan organisasi dengan jelas.

Budaya organisasi dapat meningkatkan komitmen organisasi pekerja karena, apabila budaya organisasi yang dikembangkan dianggap positif dan kondusif, akan cenderung mendatangkan sikap positif dari pekerja. Dalam hal ini, pekerja akan mengidentifikasi dirinya secara lebih kuat dengan nilai-nilai dan tujuan organisasi. Rasa identifikasi diri yang lebih erat ini mendorong munculnya sikap positif dalam diri pekerja yang tercermin dari adanya dorongan yang lebih kuat untuk berpartisipasi aktif dan bertahan dalam organisasi.

Temuan dalam studi ini yang mendapati ada hubungan positif variabel budaya organisasi terhadap komitmen organisasi dosen selaras dengan hasil studi Ghina (2012). Terkait dengan hasil studinya, Ghina (2012) lebih lanjut menyatakan bahwa penting bagi organisasi untuk mengembangkan budaya yang suportif dan demokratis, yakni budaya yang mendukung kemajuan setiap anggota organisasi, dalam rangka membangun komitmen dosen terhadap organisasi. Sebagaimana dijelaskan dalam studi Ghina (2012), seluruh aspek yang melekat di dalam variabel budaya organisasi, seperti kerjasama, komunikasi, reward dan hukuman, mempunyai hubungan yang positif terhadap komitmen organisasi. 
Shoaib, et al, (2013) dalam studinya berupaya menganalisis hubungan budaya organisasi terhadap komitmen organisasi. Lebih lanjut, di dalam studinya, Shoaib, membagi jenis budaya organisasi ke dalam empat jenis yang meliputi clan culture, adhocracy culture, hierarchy culture dan market culture. Selain itu, ia juga membagi komitmen organisasi ke dalam tiga jenis, yakni affective commitment, continuance commitment, dan normative commitment. Hasilnya Shoaib, menemukan bahwa clan culture memiliki hubungan positif yang lebih kuat dan signifikan terhadap ketiga jenis komitmen organisasi yang dianalisis daripada adhocracy, hierarchy, atau market culture. Ini karena, menurut Shoaib, pada clan culture dosen dilihat sebagai anggota keluarga (family members). Dalam kondisi yang akrab seperti ini, dosen akan merasa lebih nyaman, sehingga berkembang rasa kepemilikan yang lebih kuat. Di sini dosen akan menumbuhkan keterikatan komitmen yang lebih erat terhadap organisasi. Dengan kata lain, dosen akan cenderung menjadi lebih berkomitmen terhadap organisasi tempatnya bekerja.

Sedangkan temuan bahwa budaya organisasi memiliki hubungan positif dan signifikan juga dapat ditemui dalam studi Siburian (2013). Dengan menggunakan guru sebagai obyek studinya, Siburian menemukan budaya organisasi sebagai salah satu faktor yang paling dominan, di antara beberapa faktor lain yang juga dianalisis, dalam memhubungani komitmen organisasi guru. Ini artinya, secara praktis, dapat dimaknai bahwa semakin baik kondisi budaya organisasi, maka komitmen organisasi guru akan semakin tinggi. Menurut Siburian (2013), yang dimaksud dengan budaya organisasi yang baik adalah budaya yang mendukung berlangsungnya penguatan perilaku positif dalam pekerjaan. Sebaliknya, budaya organisasi yang dianggap kurang baik adalah budaya yang mendorong munculnya perilaku yang tidak pantas (improper action) dalam pekerjaan karena ada ketidakjelasan pengarahan (direction) dalam organisasi.

Peran penting budaya organisasi dalam menumbuhkan komitmen dosen juga ditemukan oleh Acar (2012). Secara lebih spesifik, Acar menemukan bahwa budaya organisasi yang menekankan pada unsur keterikatan emosional yang kuat, seperti pada hubungan persaudaraan, memiliki hubungan yang kuat terhadap affective commitment. Sementara itu, budaya organisasi yang menekankan pemberian fasilitas dan dorongaan untuk bisa mengembangkan diri, hubungannya lebih besar terhadap normative commitment. Menurut Acar (2012), dengan merujuk pada hasil penelitian-nya, penting bagi organisasi untuk mengembangkan budaya yang menekankan pada aspek fleksibilitas dan diskresi. Ini karena budaya organisasi yang fleksibel dan mendorong munculnya perilaku kolektif bisa menumbuhkan komitmen dosen terhadap organisasi.

\section{DAFTAR PUSTAKA}

Acar, Z. (2012). Organizational Culture, Leadership Style, and Organizational Commitment in Turkish Logistics Industry. Social and Behavioral Sciences: Vol. 58, Hal. 217 - 226.

Alvi, H. A., Hanif, M., Adil, M. S. (2014). Impact of Organizational Culture on Organizational Commitment and Job Satisfaction. European Journal of Business and Management: Vol. 6, No. 22.

Baqer, K. (2012). A Cross-Cultural Study of Job Satisfaction and Organizational Commitment of Bank Employees of Iran and India. Journal of Basic and Applied Scientific Research: Vol. 2, No. 1, Hal. 605609.

Ghina, A. (2012). The Influence of Corporate Culture on Organizational Commitment: Case Study of Civil Government Organizations in Indonesia. International Journal of Applied Science: Vol. 1, No. 2.

Greenberg, J., Baron, R. A. (2012). Behavior In Organization. Nineth Edition. New Jersey: Prentice Hall. 
Greenpeace. (2013). Laut Indonesia Dalam Krisis. Kajian Lembaga Greenpeace.

Hasibuan, H. Malayu, S. P. (2010). Manajemen Sumberdaya Manusia. Jakarta: Bumi Aksara.

Imam, A., Raza, A., Ahmed, M. (2014). Impact of Job Satisfaction on Organizational Commitment in Banking Sector Employees of Pakistan.

Manetje, O., Martins, N. (2009). The Relationship Between Organisational Culture and Organisational Commitment. Southern African Business Review: Vol. 13, No. 1.

Meyer, J. P., Allen, N. J. (1990). The Measurement and Variables Associated With Effective, Continuance and Normative Commitment to the Organization. Journal of Occupational Psychology: Vol. 63, Hal. 1-18.

Meyer,J.P.,Allen, N.J.(1991).AThreeComponent Model of Organizational Commitment. Journal of Applied Psychology: Vol. 79, Hal. 15-23.

Meyer, J. P., Stanley, D. J., Herscovitch, L., Topolnytsky, L. (2002). Affective, Continuance and Normatie Commitment to the Organization. Journal of Vocational Behavior: No. 61, Hal. 20-52.

Nongo, E. S., Ikyanyon, D. N. (2012). The Influence of CorporateCulture on Employee Commitment to the Organization. International Journal Business and Management: Vol. 7, No. 22.

Robbins, S. P.(2010). Perilaku Organisasi. Terjemahan Benyamin Molan, Jakarta: PT. Indeks.

Robbins, S. P., Judge. T. (2011). Organizational Behavior. New Jersey: Pearson Prentice Hall.

Robbins, S. P., T. Judge.(2009). Organizational Behavior. New Jersey: Pearson Prentice Hall.
Schein, E. H. (2010). OrgnizationaI Culture and Leadership, Third Edition, CA, SanFransisco: Jossey-Bass.

Schein, E. H.(2004) Organizational Culture and Leadership. San Fransisco: Jossey-Bass.

Sekaran, U. (2010). Research Methods: A Skill Building Approach. New York: John and Wiley.

Shoaib, A., Zainab, H., Maqsood, H., Rafiq, S. (2013). Impact of Organizational Culture on Organizational Commitment. Research Journal of Recent Sciences: Vol. 2, Hal. 1520.

Siburian, T. A. (2013). The Effect of Interpersonal Communication, Organizational Culture, Job Satisfaction and Achievement Motivation to Organizational Commitment of State High School Teacher in the District Humbang Hasundutan, North Sumatera, Indonesia. International Journal of Humanities and Social Sciences: Vol. 3, No. 16.

Silverthorne, C. (2004). The Impact of Orgnizational Culture and Personorganization fit on Organizational Commitment and Job Satisfaction in Taiwan. The Leadership and Organizational Development Journal: Vol. 25 No. 7.

Tahere, N., Zahra, G. T., Fateme, D., Asma, Y. J. (2012). Investigating the Effect of Job Experience, Satisfaction, and Motivation on Organizational Commitment Case Study: The Nurses of Ghaem Hospital in Mashhad. Research Journal of Recent Studies.

Zain, Z. M., Ishak, R., Erlane, K. G. (2009). The Influence of Corporate Culture on Organizational Commitment: A Study on a Malaysia Listed Company. European Journal of Economics, Finance and Admnistrative Sciences. 